\title{
Obietnice Ducha dla „martwych” w świetle Ap 14,13
}

\author{
Promises of the Spirit for "the Dead" in the Light of Rev 14:13
}

TOMASZ SIEMIENIEC

Katolicki Uniwersytet Lubelski Jana Pawła II

tsiemi@poczta.onet.pl; ORCID: 0000-0002-5835-8908

Streszczenie: Artykuł porusza kwestię obietnic Ducha dla „martwych” w świetle Ap 14,13. Punktem wyjścia jest stan badań nad tekstem Ap 14,13. Zostało wykazane, że - jak dotąd - uczeni głownie skupiali się na adresatach tego makaryzmu, poszukując odpowiedzi na pytanie o to, czy idzie tutaj o wszystkich chrześcijan, czy tylko o męczenników. Autor artykułu proponuje rozumieć „martwych” w kategoriach duchowych (jako martwych duchowo). Wskazuje na to kontekst makaryzmu, którym jest wizja 14,6-13, jak również fakt, że duchowe znaczenie terminu „martwi” nie stoi w sprzeczności z innymi tekstami Apokalipsy. W związku z tym mamy tu błogosławieństwo dla tych, którzy się nawracają. Duch Święty jawi się tutaj jako Ten, który potwierdza obietnice dane w makaryzmie, a co za tym idzie, jest Tym, który nadaje dynamizm głoszonej „odwiecznej dobrej nowinie”. Duch, przemawiając w Ap 14,13, jawi się jako Osoba, która wyraża siebie samego, przekazując orędzie ludziom. Paralelne do wypowiedzi Ducha polecenie spisania treści błogosławieństwa ukazuje rolę tegoż Ducha w procesie, który nazywamy natchnieniem skrypturystycznym. Zatem Duch odgrywa tutaj bardzo ważną rolę w przekazie dobrej nowiny, która z jednej strony wzywa do nawrócenia, a z drugiej, w przypadku, kiedy to nawrócenie nastąpi, wskazuje na rychłą realizację zbawczych obietnic.

Słowa kluczowe: Apokalipsa św. Jana, Duch Święty, makaryzm, błogosławieństwo

Abstract: The article deals with the problem of promises of the Spirit for "the Dead" in the light of Rev 14:13. The point of departure for this analysis is the presentation of the current state of research. It has been demonstrated that, until now, scholars have focused on the question of the recipients of this macarism, whether it applies to all Christians or merely martyrs. The author of the article proposes to understand "the dead" as spiritually dead. This meaning is indicated by the context of the macarism, which is the whole vision in Rev 14:6-13, as well as by the fact that this spiritual sense of the term "the dead" does not contradict other texts of Revelation. Thus we have here a blessing for those who repent. The Holy Spirit shows himself here as the one who confirms the promises given in the blessing, and consequently as the one who animates the eternal gospel being proclaimed. The Spirit, speaking in Rev 14:13, reveals himself as a person who expresses himself by delivering the message to humankind. The command to write the content of the blessing (v. 13a), parallel to the Spirit's statement (v. 13b), reveals the role of this Spirit in the process, called "a scripturistic inspiration". Therefore the Spirit plays here an important role in the transmission of the eternal gospel which, first, calls for repentance, and, when repentance is forthcoming, promises an early accomplishment of salvific promises.

Keywords: Book of Revelation; Holy Spirit; macarism, beatitude 
W porównaniu z innymi pismami Nowego Testamentu Apokalipsa zawiera niezbyt dużo wzmianek o Duchu Świętym. Na podstawie tych tekstów trudno jest tworzyć jakiś systematyczny traktat o Duchu Świętym, choć nie oznacza to, że pneumatologia Apokalipsy jest nieistotna ${ }^{1}$. Samo wyrażenie „Duch Święty” nie występuje w niej, pojawia się natomiast termin „Duch” ( $\pi v \varepsilon v \tilde{\mu \alpha})$. Zauważalne są również pewne symbole odnoszące się do trzeciej Osoby Trójcy Świętej (np. świeczniki). Przede wszystkim trzeba zauważyć, że obraz Ducha Świętego w ostatniej księdze Nowego Testamentu jest ściśle powiązany z jej eklezjologią. Duch Święty jest tam bowiem ukazany jako ten, który „mówi do Kościołów”, przekazując orędzie Jezusa Chrystusa. Duch jest także tym, który daje objawienie Janowi. Cztery razy w księdze pojawia się stwierdzenie Jana, że Duch oddziaływał na niego (był દ̇v $\pi v \varepsilon \dot{\mu} \mu \alpha \tau$ - Ap 1,10;4,2; 17,3; 21,10), umożliwiając przekazanie proroctwa. Oprócz tego w dwóch miejscach Apokalipsy przytoczone zostały słowa Ducha $(14,13$ i 22,17$)$.

Celem niniejszego opracowania jest ukazanie orędzia, jakie Duch kieruje do „martwych” w makaryzmie zawartym w Ap 14,13. Wagę tego błogosławieństwa podkreśla fakt, że jako jedyne w całej Apokalipsie powiązane jest ono z poleceniem zapisania go. Tekst ten często wykorzystywany jest w liturgii chrześcijańskiego pogrzebu i - według najbardziej popularnej interpretacji - odnoszony do sprawiedliwych, którzy umierają w łączności z Panem, przez co otwiera się przed nimi zbawienie. Punktem wyjścia naszych analiz będzie odpowiedź na pytanie o tożsamość adresa-

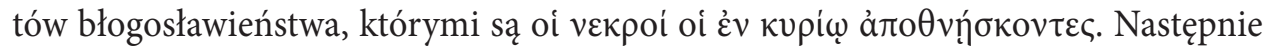
dokonana zostanie analiza tego, co mówi Duch do „martwych”. Wreszcie ostatnim elementem będzie ukazanie roli Ducha Świętego w świetle Ap 14,13.

\section{Stan badań nad Ap 14,13}

W historii badań nad Apokalipsą Janową można zauważyć zainteresowanie egzegetów występującymi w tej księdze makaryzmami (błogosławieństwami). Pośród nich jest także błogosławieństwo zawarte w Ap 14,13, skierowane do umarłych². Badania

1 Pneumatologia Apokalipsy była przedmiotem badań wielu egzegetów, zarówno polskich, jak i zagranicznych. Na pierwszym miejscu trzeba tu wymienić monografię Dariusza Koteckiego Duch Święty w zgromadzeniu liturgicznym w świetle Apokalipsy św. Jana. Ponadto zauważyć można pomniejsze opracowania w formie artykułów: np. Rand, „...Let Him Hear What the Spirit Says...”; Bauckham, „The Role of the Spirit" (najpierw opublikowany jako artykuł w Evangelical Quarterly, a następnie, jako część dzieł zebranych, w książce The Climax of Prophecy); Bauckham, The Theology of the Book of Revelation (rozdział 5 zatytułowany The Spirit of Prophecy, 109-125); Smalley, „The Paraclete”; Smidt, „Hermeneutical Perspectives”; G. Biguzzi, „Spirito e profezia”.

2 Zob. np. opracowania o charakterze przekrojowym: Bieder, „Die sieben Seligpreisungen”; Haręzga, Błogosławieństwa Apokalipsy; Nwachukwu, Beyond Vengeance and Protest. Zob. ponadto analizę Ap 1,3;14,13;16,15; 19,9; 20,6;22,7.14 u różnych komentatorów (np. Giesen, Die Offenbarung; 
egzegetów pochylających się nad tym wersetem idą w kierunku poszukiwania odpowiedzi na kilka pytań. Po pierwsze, chodzi o kwestię adresatów wspomnianego błogosławieństwa. Czy są nimi wszyscy chrześcijanie, czy tylko męczennicy (wówczas wzmiankowane tutaj „trudy” oznaczałyby prześladowanie)?3 Po drugie, zainte-

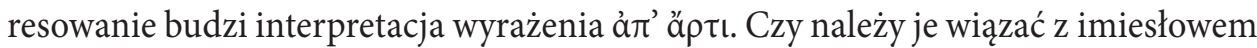

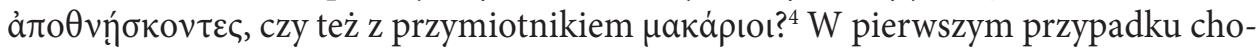
dziłoby o to, że szczęśliwi są ci, który odtąd (tzn. od zaistnienia wydarzeń opisanych w Apokalipsie - zwłaszcza od momentu, kiedy odniesione zostało zwycięstwo nad przeciwnikami Boga) umierają. W drugim - o to, że ci, którzy umierają, są już teraz szczęśliwi (zanim nastąpi pełna realizacja zbawienia). Po trzecie, powstaje pytanie o ewentualny związek wersetu 13 z kontekstem, w którym się pojawia. Czy przypadkiem nie jest on w tym miejscu „ciałem obcym” sztucznie wprowadzonym przez autora? ${ }^{5}$ Oprócz opracowań poszukujących odpowiedzi na powyższe pytania spotkać można analizy wspomnianego wersetu, które dokonywane są w ramach badania różnych innych zagadnień szczegółowych ${ }^{6}$.

Spojrzenie na Ap 14,13 stawia czytelnika przed kilkoma pytaniami, na które dotychczasowe analizy nie dały odpowiedzi. Po pierwsze, chodzi o swego rodzaju niekonsekwencję czasową. Adresatami błogosławieństwa są oi vekpoí (martwi), czyli ci, którzy już nie żyją. W takiej sytuacji zastanawia, dlaczego zostali oni zestawieni

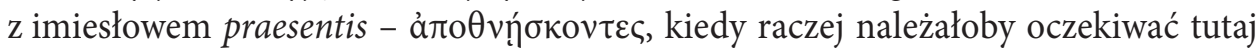
imiesłowu aoristi (ew. perfecti). Wówczas przekład brzmiałby „szczęśliwi umarli, którzy zmarli w Panu”. Obecnie natomiast tekst grecki sugeruje inny przekład: „szczęśliwi martwi, którzy umierają w Panu" "Tę osobliwość badacze tłumaczą w różny sposób, na przykład odwołując się do osobliwego stylu Jana, który miał pisać po grecku, ale myśleć po hebrajsku', czy też wskazując na swoistą linię chronologiczną Apokalipsy, która kwalifikuje czas ukazany w tej księdze jako „czas metahistoryczny”.

Beale, The Book of Revelation; Wojciechowski, Apokalipsa). Makaryzm Ap 14,13 w kontekście całej wizji 14,6-13 z socjoretorycznego punktu widzenia bada DeSilva, „A Sociorhetorical Interpretation”.

3 Zob. np. Bousset, Die Offenbarung, 386-387; Yeatts, Revelation, 270; Beale, The Book of Revelation, 767-768; Gundry, Commentary on Revelation, 2442-2453; Blount, Revelation, 4664-4668.

4 Zob. np. Mounce, The Book of Revelation, 275; Krodel, Revelation, 271; Morris, Revelation, kom. do 14,13; Beale, The Book of Revelation, 767-768.

5 Np. Charles, A Critical and Exegetical Commentary, 368-373; David E. Aune (Revelation 6-16, 839) mówi o interpolacji powstałej przy ostatecznej redakcji księgi.

6 Zob. np. Kotecki, Duch Swięty, 393-402.

7 Z polskich najnowszych przekładów Biblia Tysiąclecia (wyd. 5) zdaje się w ogóle pomijać w przekładzie przymiotnik oi vekpoi tłumacząc: „Błogosławieni, którzy w Panu umierają”. Z kolei Biblia Paulistów ma: „....szczęśliwi są umarli, którzy umierali w Panu”.

8 Por. Charles, A Critical and Exegetical Commentary, 332-334, który wiąże Ap 14,12-13 z sekcją 12,18-13,18 i uważa, że pierwotnie następowały one po 13,18. Hipotezę tę zauważa Heinrich Kraft (Die Offenbarung, 195), wskazując jeszcze na możliwość umiejscowienia tych wersetów po 12,17, choć - jak sam stwierdza - przesuwanie wersetów w inne miejsce stanowi anulowanie działań ostatecznego redaktora księgi.

9 Por. Kotecki, Duch Święty, 395. 
Nie kwestionując tych ustaleń, można jednak zapytać, czy za ową „niekonsekwencją” czasową nie kryje się jakiś szczególny zamysł autora. Po drugie, zwrócenie uwagi na najbliższy kontekst Ap 14,13, który stanowi wizja zaczynająca się od kaì عĩov w 14,6 i kończąca się właśnie w 14,13 (ponieważ w 14,14 mamy ponownie kaì عĩoov, które rozpoczyna kolejną wizję), rodzi pytanie o miejsce analizowanego makaryzmu w całej tej wizji. Stanowi ona coraz bardziej natarczywe wezwanie do nawrócenia zarówno w obliczu upadku Babilonu, jak i zapowiedzi wiecznej kary, która czeka czcicieli Bestii. W związku z tym zaskakuje wzmianka o „odwiecznej ewangelii”, którą rozpoczyna się cała wizja w 14,6. Można bowiem stawiać pytanie o to, jaka „dobra nowina” zawarta jest w opisie kary, który daje się dostrzec, poczynając od 14,7. W takiej sytuacji można na poziomie treści dostrzec następujący schemat: 1) zapowiedź uniwersalnej dobrej nowiny, która ma postać apelu - przestrogi (w. 6-7);2) ukazanie sądu jako wydarzenia już dokonanego (w. 8); 3) zapowiedź kary dla niewiernych (w. 9-12); 3) końcowe błogosławieństwo (w. 13). Kiedy to uwzględnimy, możemy dojść do wniosku, że owo błogosławieństwo, jawi się jako tematycznie nie do końca pasujące do całej wizji ${ }^{10}$.

Biorąc pod uwagę potrzebę ponownego zdefiniowania adresatów omawianego błogosławieństwa, na które znaczący wpływ ma najpierw pewna niekonsekwencja czasów użytych w ich prezentacji, jak również kontekst, w jakim cały makaryzm występuje, należy zauważyć, że skutkuje to koniecznością odczytania na nowo kierowanego przez Ducha Świętego orędzia. Dotychczas bowiem interpretowano makaryzm Ap 14,13 jako zachętę do wytrwałości, którą Duch Święty kieruje do wiernych, stojących w obliczu prześladowania ze strony sił wrogich Bogu, zapewniając ich, że trwając w stanie wierności aż do śmierci, zasłużą na miano szczęśliwych. Ponowne pochylenie się nad tym zagadnieniem może wprowadzić nowe spojrzenie na rolę Ducha Świętego w tym dziele i na treść orędzia, które On kieruje.

\section{2. "Martwi” jako adresaci makaryzmu Ap 14,13}

Punktem wyjścia jest tutaj propozycja ujęcia struktury całej wizji zawartej w Ap 14,6-13. Łatwo zauważyć, że w ramach tej wizji powtarzającym się motywem

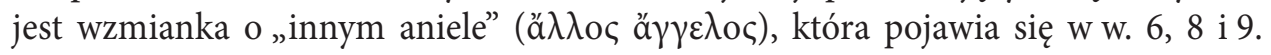
Zatem można tutaj wyróżnić trzy mniejsze jednostki (w. 6-7; 8 i 9-13). Innym zjawiskiem, także łatwym do dostrzeżenia, jest pewna niekonsekwencja odnośnie do

10 Przekonanie takie pojawia się wśród badaczy, którzy zauważają, że 14,13 stanowi przerwanie toku narracji w Apokalipsie. Zob. np. Swete, The Apocalypse of St John, 186; Wilfrid J. Harrington (Revelation, 152) uważa, że Jan najpierw (w. 9-12) straszy adresatów, by potem (w. 13) ich pocieszyć, zatem stosuje znaną metodę „kija i marchewki”. 
stosowania liczby pojedynaczej i mnogiej, jaka zachodzi między wersetami 10 i 11 . Werset 10 (który jest ściśle związany z wersetem wcześniejszym) używa liczby pojedynczej (w. 9b: „jeśli ktoś”...; w: 10: „ten będzie pić wino... będzie katowany”), podczas gdy werset 11 nagle wprowadza liczbę mnogą („dym ich katuszy”). Biorąc to pod uwagę, można zaproponować inną strukturę, która ma charakter koncentryczny. Wyróżnić w niej można następujące elementy: a) 14,6-7 i a’) 14,13; b) 14,8 i b’) 14,11 ; c) 14,9-10. Tym, co wyznacza podział na elementy: a, b i c, jest wzmianka o pojawieniu się następnego anioła. Z kolei, naszym zdaniem, poczynając do 14,10 mamy rozwinięcie tego, o czym była mowa przy wystąpieniu kolejnych aniołów. Na przykład 14,10 wykazuje ścisły związek z wersetem wcześniejszym, na co wskazuje

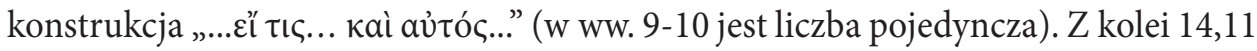
zdaje się rozwijać to, co zostało powiedziane w 14,8. Tam bowiem mowa jest o Wielkim Babilonie oraz o „wszystkich narodach”, zaś w wersecie 11 - o dymie ich (liczba mnoga) katuszy. Powiązanie wznoszącego się na wieki wieków dymu katuszy z upadkiem Babilonu jest oczywiste, kiedy uwzględnimy 19,3, gdzie takie powiązanie funkcjonuje. Oczywiście w ramach tej struktury można dostrzec pewne znaki zapytania, jak choćby końcową część wersetu 11, gdzie powraca liczba pojedyncza, i wersetu 12, gdzie pojawia się wyglądająca na wtrącenie wypowiedź: „tu okazuje się wytrwałość świętych, tych, którzy strzegą przykazań Boga i wiary Jezusa" ${ }^{\prime 1}$.

Gdyby przyjąć powyższą strukturę, oznaczałoby to, że makaryzm w 14,13 stanowi dopowiedzenie do tego, co zawarte jest w 14,6-7. W związku z tym, należy zapytać o to, czy istnieje jakiś związek między „siedzącymi na ziemi” $(14,6)$

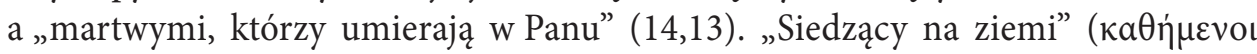

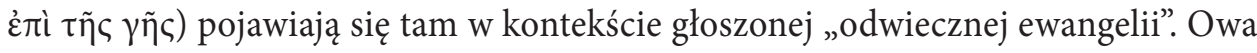

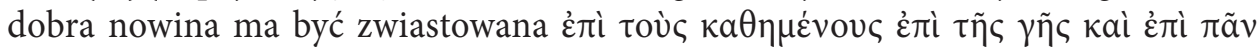

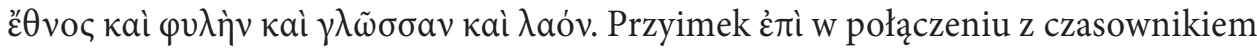

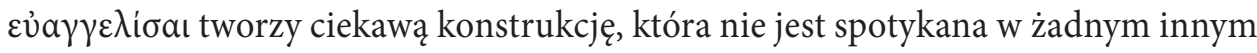
tekście biblijnym. Zwykle bowiem wspomniany czasownik łączy się z dopełnieniem $\mathrm{w}$ dativie (wskazując na adresatów orędzia) lub w accusativie (wskazując na to, co jest zwiastowane). Roman Lebiedziuk, analizując Ap 14,6, zastanawia się, czy przypadkiem wspomnianego przyimka ėđi nie należy interpretować w znaczeniu „odnośnie do”. Tak czyni np. Heinz Giesen, który uważa, że adresatami dobrej nowiny

11 Naszym zdaniem można podjąć próbę wyjaśnienia tych znaków zapytania. Powrót liczby pojedynczej w 14,11b może służyć temu, aby powiązać fakt bycia czcicielem Bestii i jej obrazu z faktem przynależności do rzeczywistości określanej mianem Wielkiego Babilonu (chodzi o powiązanie aspektu zbiorowego z indywidualnym). Oddawanie czci Bestii i jej obrazowi jest de facto nierządem, o którym mowa w 14,8b. Z kolei werset 14,12 zdaje się rzeczywiście nie pasować do kontekstu. D. Kotecki (Duch Święty, 392) stwierdza, że wiersz ten przerywa nić narracyjną, być może po to, by umożliwić wspólnocie głębszą refleksję nad tym, co wynika z usłyszanej wizji. Podobną funkcję może mieć paralelne wyrażenie w 13,10. Z kolei Pierre Prigent (Commentary, 445) wyróżnia kilka takich wtrąceń (oprócz 13,10 i 14,12, także 13,18 i 17,9) i uważa, że Jan chce tutaj zwrócić się bezpośrednio do adresatów, by pokazać związek, jaki istnieje między tym, co opisuje, a życiem chrześcijan. Por. także Aune, Revelation 6-16, 798. 
są tutaj chrześcijanie, a cała wizja ma na celu ich umocnienie, zaś jej treścią są losy tych, którzy stoją w opozycji do Boga („mieszkańców ziemi”). Zatem miałaby to być dobra nowina dla wiernych, którzy widząc sąd nad nieprawymi, zostaliby ugruntowani $\mathrm{w}$ swej wierze zarówno $\mathrm{w}$ obliczu prześladowań, jak i promocji kultu imperialnego ${ }^{12}$. Lebiedziuk zauważa, że w Apokalipsie wyrażenie „mieszkańcy ziemi” jest teologiczną kategorią, która wskazuje na ludzi przeciwnych Bogu, Barankowi i Jego naśladowcom $(6,10 ; 11,10 ; 13,8.12 .14 ; 17,2.8)$. Oznacza zatem tych, którzy są poddani wpływom Bestii i związani z bałwochwalczym systemem określanym mianem Wielkiego Babilonu. $Z$ drugiej strony jednak, jak zauważa egzegeta, istnieją przesłanki, aby w 14,6 złagodzić radykalnie negatywny obraz tej kategorii ludzi i potraktować ich jako potencjalnych adresatów dobrej nowiny ${ }^{13}$. Możliwe, że temu

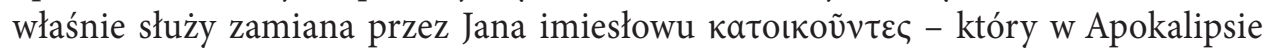
pojawia się wszędzie tam, gdzie mowa jest o „mieszkańcach ziemi” - na imiesłów

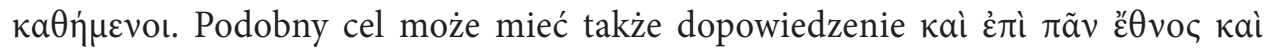

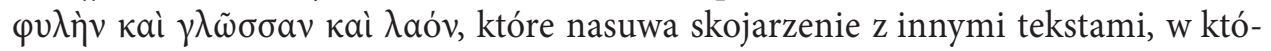
rych ono się pojawia, takimi jak 5,$9 ; 7,9 ; 14,3.4$. Teksty te mają pozytywną wymowę, mówią np. o wykupionych przez Baranka, czy też o oddających cześć Bogu i Barankowi. W związku z tym mielibyśmy tutaj „mieszkańców ziemi” jako tych, którzy są zdolni do nawrócenia, czyli są potencjalnymi czcicielami Boga i Baranka ${ }^{14}$. W takiej sytuacji zwiastowana odwieczna dobra nowina, wzywająca do nawrócenia, ma rzeczywiście sens. Tym właśnie, co decyduje o jej „dobrym” charakterze jest owa potencjalna zdolność do oddania przez „mieszkańców ziemi” chwały Bogu. Nie są oni przekreśleni, ale są adresatami ewangelii. O tym, że idzie tutaj o wezwanie do nawrócenia świadczy także podwójne wezwanie zawarte w 14,7: $\varphi \circ \beta \eta \dot{\eta} \theta \eta \varepsilon$

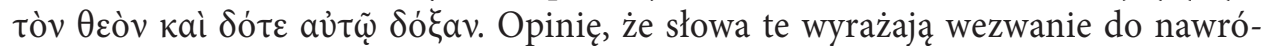
cenia potwierdza choćby zestawienie ich z Ap 11,13, gdzie nawrócenie mieszkań-

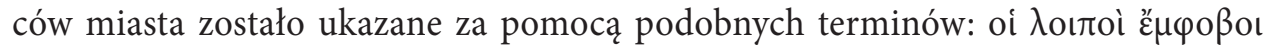

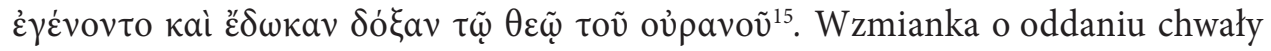
Bogu pojawia się w Apokalipsie w kontekście kultycznym (4,11; 5,13; 7,12; 19,5), co oznacza, że zewnętrznym znakiem nawrócenia jest porzucenie kultu bałwochwalczego i oddanie Bogu czci poprzez udział w liturgii ludu Bożego (wskazuje na to

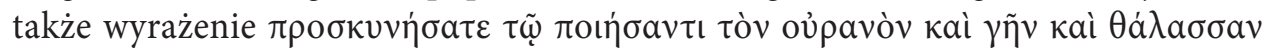

12 Por. Giesen, Evangelium und Paränese, 98.

13 Por. Lebiedziuk, „Apokalipsa 14,6”, 74. Za tym, że غ̇đí może wskazywać na mieszkańców ziemi jako adresatów Ewangelii (a nie jej treść) opowiada się także C.R. Koester (Revelation, 612), odwołując się do BDAG $402 \$ 1$.

14 Por. Lebiedziuk, „Apokalipsa 14,6”, 75.

15 Por. Aune, Revelation 6-16, 827; Siemieniec, Teologiczna rola „ludzi”, 400-401. Warto także odwołać się do Joz 7,19, gdzie mowa jest o Akanie, wzywanym do uznania swojego grzechu: $\delta$ ò $\delta$ ó $\xi \alpha$. W Ap 16,9 mamy

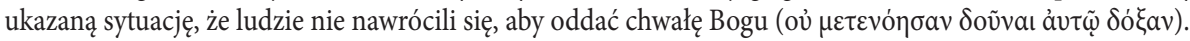




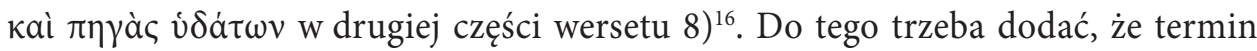

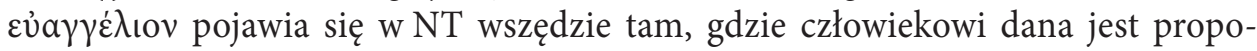
zycja przyjęcia zbawienia, z której wynika jednocześnie wezwanie do nawrócenia (np. Mk 1,15; 16,15-16; Rz 1,16) ${ }^{17}$. Ewangelia określona została mianem „odwiecznej" (aỉuvıov). Określenie to należy interpretować w kontekście całej tradycji Janowej, gdzie odnosi się do rzeczywistości zainaugurowanej przez dzieło Jezusa Chrystusa. Chodzi o nastanie czasów ostatecznych, wkroczenie tego, co wieczne, ponadczasowe, związane $\mathrm{z}$ Bogiem $\mathrm{w}$ ramy czasowe związane $\mathrm{z}$ funkcjonowaniem ludzkości. Od momentu, kiedy zaczęła się realizacja misji Chrystusa, to, co związane z wiecznością staje się dostępne dla ludzi. W obliczu tego człowiek nie może pozostać obojętny, ale musi się opowiedzieć za przyjęciem tej rzeczywistości bądź przeciw niej. W tym kontekście odwieczna ewangelia obejmuje także zwiastowanie sądu. Sposób jej ogłoszenia - poprzez anioła lecącego środkiem nieba - wskazuje, że jest ona zaadresowana do całego świata ${ }^{18}$. Zatem w 14,7 mamy ukazaną ostateczną szansę na nawrócenie w obliczu nadchodzącego sądu. Jest ona dana tym wszystkim, którzy do tej pory pogrążeni byli w bałwochwalstwie.

Zauważyliśmy wcześniej, że koncentryczna struktura 14,6-13 pozwala na powiązanie adresatów odwiecznej ewangelii z 14,6 z adresatami makaryzmu w 14,13. Są nimi „martwi” (oi vekpoi). Termin ten w Apokalipsie zdaje się mieć znaczenie duchowe, to znaczy wskazuje na martwych duchowo. Można tu odwołać się przede wszystkim do 3,1, gdzie do wspólnoty w Sardes skierowane zostały słowa oĩ $\delta \dot{\alpha}$ бov

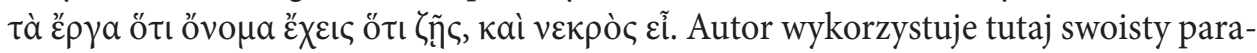
doks, łącząc dwie metafory za pomocą kai adversativum. Rzeczownik ővoua, oprócz „imienia”, może odnosić się także do godności, autorytetu czy reputacji. W tym kontekście owa reputacja zależy od postępowania członków wspólnoty. Zewnętrzne pozory wskazują na żywotność lokalnego Kościoła (stąd mowa o tym, że ötı ővora

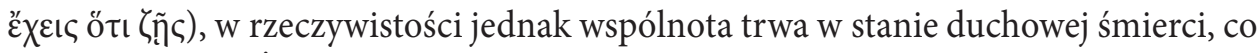
dostrzega Jezus. Życie bez więzi z Bogiem (czy też Chrystusem) jest de facto stanem śmierci. Ci, którzy oddają pokłon bałwochwalczy Bestii, choć fizycznie żywi, z Bożej perspektywy traktowani są jako martwi, ponieważ utracili oni blask duchowej chwały, czyli stan łaski, życia z Bogiem ${ }^{19}$. Nie jest to jednak stan, którego nie można odmienić, co podkreślone zostało przez wezwanie do bycia czujnym i do nawrócenia

\footnotetext{
16 Por. Koester, Revelation, 612.

17 Bauckham (The Climax of Prophecy, 286-287) we wzmiance o zwiastowaniu odwiecznej ewangelii

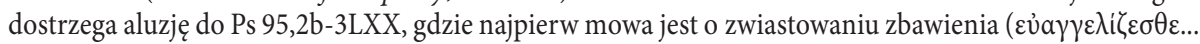

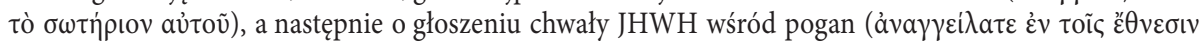

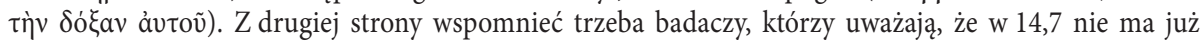
propozycji zbawienia, a jedynie ogłoszenie sądu. Tak uważają np. R.H. Mounce i G.K. Beale.

18 Osborne, Revelation, 534; Prigent, Commentary, 438-439.

19 Nwachukwu, Beyond Vengeance and Protest, 110.
} 


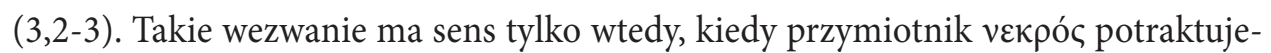
my w kategoriach duchowych ${ }^{20}$.

Biorąc to pod uwagę możemy zauważyć, że makaryzm w 14,13 wiąże się ściśle $\mathrm{z}$ „odwieczną ewangelią" proklamowaną w 14,6. Owa ewangelia zawiera ostatnie wezwanie do nawrócenia zaadresowane do tych, którzy do tej pory byli bałwochwalcami, czyli w duchowym znaczeniu byli martwi. Ap 14,13 stanowi dopowiedzenie do tego, wskazując, jaki los czeka tych, którzy - dotąd „martwi” - jednak się nawracają i oddają chwałę Bogu.

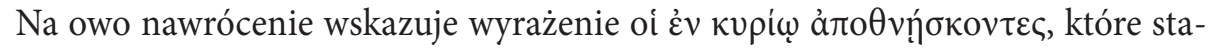
nowi dopowiedzenie do terminu oi veкpoí. W ten sposób podkreślone zostało, że

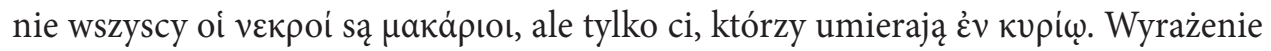
„W Panu” (ewentualnie „w Jezusie”) charakterystyczne jest nie dla Apokalipsy, lecz dla tradycji Pawłowej (gdzie pojawia się ok. 45 razy) i wskazuje na łączność chrześcijanina z Chrystusem, pozostawanie z Nim w żywotnej więzi, obejmującej różne

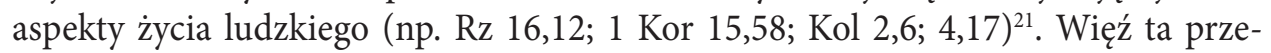
kracza granice fizycznej śmierci, co widać np. w 1 Kor 15,18.22 czy 1 Tes 4,1622. W Ap 14,13 istotne jest, że ów stan więzi z Panem jest aktualny w momencie fizycznej śmierci. W przypadku „martwych”, o których tutaj mowa, można przypuszczać, że idzie o stan więzi odzyskanej dzięki nawróceniu. Innymi słowy, nawet ten, kto

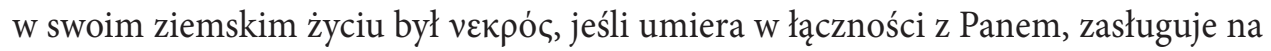
miano szczęśliwego.

W tym kontekście rozjaśnia się nieco znaczenie dyskutowanego wyrażenia ảં’

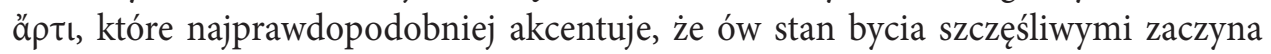
się już teraz - w momencie ich śmierci „w Panu”. W ten sposób ukazana została niezwykła odmiana ich losu. Fakt nawrócenia tych, którzy dotąd byli vekpoi sprawia, że pełnia zbawienia staje się natychmiast ich udziałem, tak samo jak jest ona udziałem męczenników ukazanych w 6,9-1123.

20 Szerzej na temat duchowej interpretacji terminu oi vekpoí w Apokalipsie zob. Siemieniec, „Kim są „umarli” w Apokalipsie?", 389-429. W podobny sposób wypowiada się 1 Hen 103,1-15, gdzie ukazany jest los nieprawych (którzy ukazani są jako martwi) i sprawiedliwych (którzy, choć fizycznie umarli, są ukazywani jako żyjący). Por. także: Siemieniec, „Tożsamość „martwych” (oi vekpoi)”, 531-550; Siemieniec, „The Concept of Judgment", 87-106.

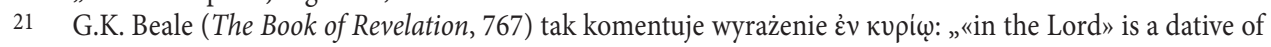
sphere, though it could also include a causal aspect; see on 1:9). Christ was rewarded after death for his endurance, and so will Christians, since Christ is their corporate representative (for this concept see on 1:20; a similar spheric or incorporative dative occurs in 1 Cor. 15:22 and 1 Thess. 4:16)". Por. Osborne, Revelation, 544.

22 Kotecki, Duch Święty, 395; Haręzga, Błogosławieństwa Apokalipsy, 51.

23 Por. Beale, The Book of Revelation, 767-768. Zob. także dyskusję na temat krytyki tekstu odnośnie do

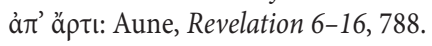




\section{Ogłoszone przez Ducha uzasadnienie błogosławieństwa}

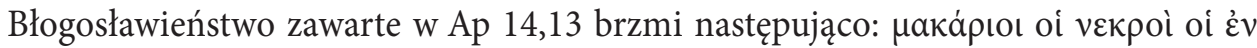

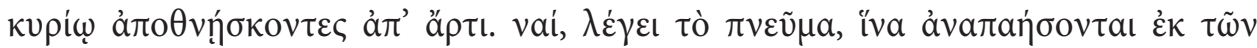

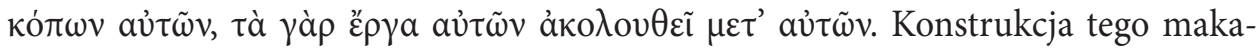
ryzmu odbiega nieco od typowej formy, która zapowiada coś pozytywnego osobie lub grupie osób reprezentujących odpowiednią postawę („szczęśliwy ten, kto...”) ${ }^{24}$. Widać bowiem wyraźnie, że błogosławieństwo składa się z dwóch części. Pierwsza ma postać typową dla makaryzmu, natomiast druga, zawierająca słowa Ducha, wzmacnia błogosławieństwo, stanowiąc jego rozbudowane uzasadnienie. Ta wypowiedź Ducha składa się z dwóch zdań. Pierwsze z nich zaczyna się od îva w połączeniu z indicativem futuri i zdaje się mieć odcień przyczynowy, choć możliwe są także

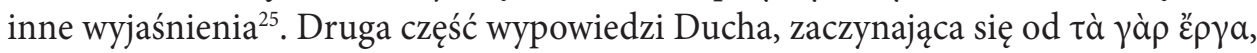
jest już klasycznym zdaniem przyczynowym.

W związku z powyższym możemy skonstatować, że błogosławieństwo 14,13 ma

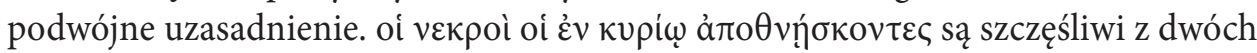

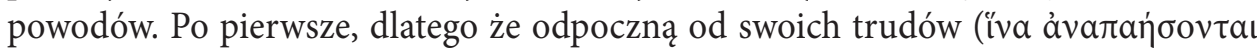

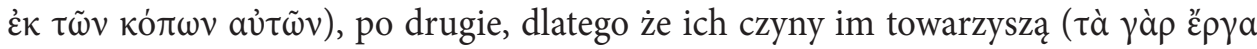

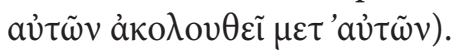

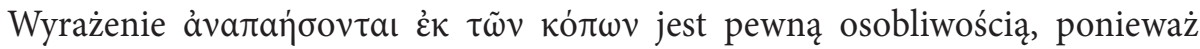

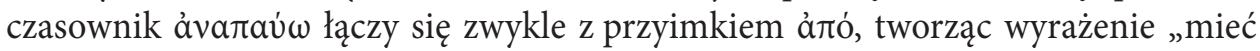
spokój, wytchnienie, odpocząć od czegoś” (np. 2 Sm 7,11LXX; Est 9,16.22LXX) ${ }^{26}$. Natomiast w połączeniu z przyimkiem ẻk czasownik ảvarav́w może mieć znaczenie „odpocząć po czymś” (por. Iz 14,3LXX) 27. Oczywiście oba znaczenia są zbliżone. Chodzi o odpoczynek, który nastaje po doświadczeniu trudów (więc jasne jest, że człowiek ich już więcej nie doświadcza).

Określenie stanu po śmierci jako odpoczynku jest ideą wywodzącą sięz judaizmu,

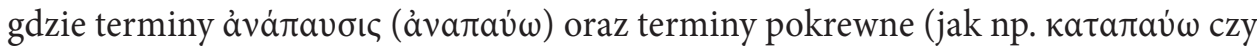

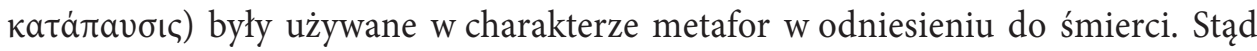
też w tekstach judaistycznych pisanych po grecku stan śmierci ukazany jest jako odpoczynek (zob. tekst grecki Prz 21,16; Syr 30,17; 38,23; 47,23 oraz Mdr 4,7). W kilku tekstach (zaliczanych do literatury międzytestamentowej) ów odpoczynek lokowany jest w niebie albo w raju (JózAs 8,11; 15,7; 22,13; 1 Hen 39,4-9; TestAbr (B) 7,9;

\footnotetext{
24 Por. Berger, Formen und Gattungen, 247-252.

25 Por. Kotecki, Duch Święty, s. 394. Egzegeta zauważa jednak, że możliwe jest, iż îva wprowadza imperatyw: „niech odpoczną”. W ten sposób oddaje ten werset wiele nowożytnych przekładów (w tym Biblia Tysiąclecia i Biblia Paulistów).

26 Por. Liddell - Scott, A Greek-English Lexicon, 115. Autorzy leksykonu przytaczają także przypadek użycia

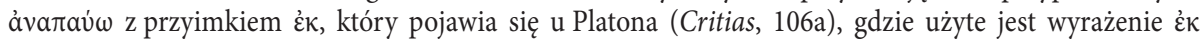

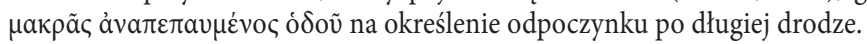


4 Ezd 7,36 ${ }^{28}$. Wydaje się, że w podobny sposób pojmuje ów odpoczynek autor Apokalipsy. Wskazuje na to fakt, że idea odpoczynku umierających w Panu kontrastu-

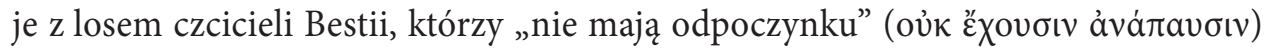
dniem i nocą $(14,11)$. Obietnica $\mu$ akápıo jest zatem paralelna do obietnicy danej męczennikom w 6,11, którzy mają odpocząć przez „krótki czas”. Można się zastanawiać, czy odpoczynek, o którym mowa w 6,11 jest tożsamy z odpoczynkiem

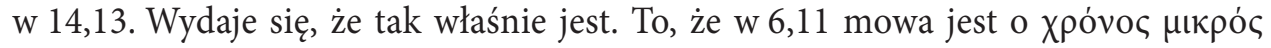
jako o czasie owego odpoczynku męczenników, wskazuje jedynie na umiejscowienie tego faktu w perspektywie interwencji Boga na rzecz prześladowanych, natomiast nie oznacza, że w pewnym momencie ów odpoczynek się skończy. W obliczu tej interwencji czas odpoczynku jawi się jako krótki, to znaczy taki, który za chwilę zostanie dopełniony działaniem Boga ${ }^{29}$. Idea odpoczynku, który staje się udziałem zarówno męczenników, jak i „martwych, którzy w Panu umierają”, ma swoją paralelę w Hbr 4,1-11, gdzie mamy swoistą teologię danego przez Boga odpoczynku. Wspomniana tam została obietnica eschatologicznego szabatu, przyobiecanego ludziom, którzy w momencie, gdy Bóg kieruje do nich swoje słowo, nie zatwardzają swych $\operatorname{serc}^{30}$.

Termin кóлоৎ pojawia się w Apokalipsie tylko w 2,2 (w liczbie pojedynczej). Możliwe, że liczba mnoga tego rzeczownika w 14,13 podkreśla intensywność czy też sumę życiowego doświadczenia wyrażonego za pomocą tego terminu. W Ap 2,2 кóлoৎ

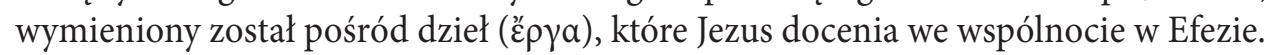
W swoim podstawowym znaczeniu wspomniany rzeczownik oznacza to, co męczy, co jest ciężkie, trudne (zarówno w wymiarze fizycznym, jak i duchowym). Wskazuje na to, co prowadzi do łez, co sprawia ból (por. Ps 9,28LXX; Ps 24,18LXX; Hi 5,6LXX; $11,16 \mathrm{LXX})^{31}$. W ten sposób Jan pokazuje, że to, co wiąże się z życiem w wierności wobec Boga jest wymagające. W kontekście wspomnianych wyżej adresatów makaryzmu możemy powiedzieć, że samo nawrócenie jest wymagające. Nie jest to coś, co przychodzi człowiekowi łatwo. Przejście ze stanu określanego za pomocą terminu oí

28 Por. Aune, Revelation 6-16, 411.

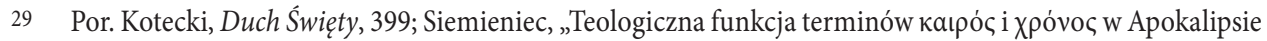
Janowej", 328-330.. E. Schüssler Fiorenza (The Book of Revelation, 49) zauważa, że wszystkie wizje i obrazy pojawiające się w Apokalipsie są zdeterminowane przez oczekiwanie bliskiego końca (tak jest np. w 10,6; $11,18 ; 12,12 ; 14,6 ; 20,3 ; 22,10)$.

30 Por. Osborne, Revelation, 545. Powiązanie idei odpoczynku z ideą eschatologicznego szabatu wydaje się jeszcze bardziej uprawnione, kiedy odwołamy się do hipotezy Anthony’ego MacPhersona, który uważa, że znamię Bestii oznacza profanowanie dnia świętego. Na ten temat zob. MacPherson, The Mark of the Beast, passim, a także: Siemieniec, Teologiczna rola „ludzi”, 297-306. W tym kontekście zrozumiałe jest, dlaczego posiadacze znamienia Bestii nie mają odpoczynku we dnie i w nocy. Ci, którzy w ziemskim życiu profanowali odpoczynek związany z dniem świętym, w wieczności pozbawieni zostaną odpoczynku.

31 Por. Muraoka, A Greek-English Lexicon, 407. W najbliższym kontekście dla Ap 2,2 pojawia się także

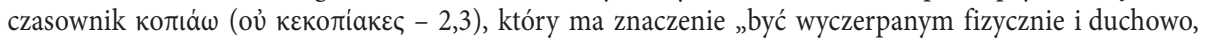
ciężko pracować dla uzyskania czegos'”. 


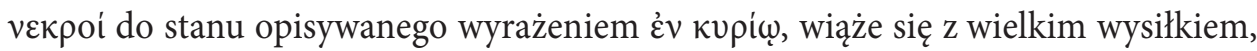
który mobilizuje wszystkie siły człowieka ${ }^{32}$.

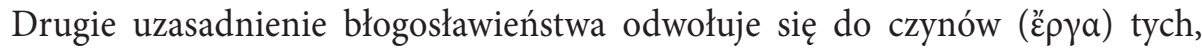

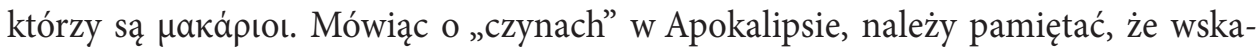
zują one na cały sposób postępowania osoby bądź społeczności. Chodzi zatem o zewnętrzne wyrażenie wartości, którymi żyje dana osoba. Stąd - jak postuluje Dariusz Kotecki - lepiej termin ép $\gamma \alpha$ oddać poprzez „aktywność, działanie, postępowanie”. Czyny bowiem zawsze objawiają wewnętrzną dyspozycję człowieka. Widać to dobrze w listach do Kościołów, gdzie wyrażenie „znam twoje czyny”, kierowane przez Jezusa do każdej ze wspólnot, stanowi wstęp do diagnozy obejmującej postawę tych wspólnot, postrzeganą w różnych aspektach $(2,2.5 \cdot 6.19 .22 .23 .26 ; 3,1.2 .8 .15)^{33}$. Idea czynów, które towarzyszą człowiekowi po śmierci jest żydowska, ale tutaj została ulokowana w kontekście chrześcijańskim. Żydowskie powiedzenie mówi, że w momencie śmierci człowiekowi nie towarzyszą srebro ani złoto, szlachetne kamienie, ani perły, lecz znajomość Tory ( $m$. Abot 6,9; por. 4 Ezd 7,35.77; 8,33). Kontekst chrześcijański wnosi w rozumienie tej prawdy nową jakość. Nie idzie już tutaj o czyny (wierność Prawu), które same z siebie dają udział wśród $\mu$ akápıol, ale o to, że wzmiankowane tutaj épүa jawią się jako owoc przyjęcia odkupienia dokonanego przez Chrystusa ${ }^{34}$.

\section{Rola Ducha Świętego w świetle Ap 14,13}

Mówiąc o roli Ducha Świętego w świetle Ap 14,13, należy przede wszystkim zauważyć, że mamy tu do czynienia z jedynym, oprócz 22,17 (należącym do epilogu księgi), tekstem, w którym przytoczone są słowa wypowiedziane przez Ducha. Nie oznacza to jednak, że Duch Święty w Apokalipsie nie odgrywa żadnego znaczenia. Wręcz przeciwnie, cała księga jest nasycona mówieniem Ducha. To Duch jest „odpowiedzialny" za siedem listów, w których mówi On do Kościołów (2,7.11.17.29; $3,6.13 .22)$. Odpowiedzialny jest za prorocką aktywność Jana (1,9.10). Nadaje On dy-

32 I.T. Beckwith (The Apocalypse of John, 447-448) wiąże кómoc, widoczny we wspólnocie w Efezie, z trudem zmagania o autentyczną wiarę. Odejście od ortodoksji jest bolesne dla wspólnoty tak, jak bolesna jest walka zmierzająca do usunięcia błędów. Na marginesie warto dodać, że w ST czasownik kođıáa pojawia się również w kontekście militarnym dla ukazania zmęczenia wynikającego z walki (np. 1 Sm 14,31; 2 Sm 17,2; 23,10 wg LXX). Do tego nawiązuje Kol 1,29.

33 Por. Kotecki, Duch Święty, 400. R.H. Charles (A Critical and Exegetical Commentary, 373) mówi, że czyny każdego człowieka są „the manifestation of his inner character”.

34 Pod. Beasley-Murray, The Book of Revelation, 228. Kotecki (Duch Święty, 401), odwołując się do P. Prigenta (Commentary on the Apocalypse, 447), zauważa też znaczącą różnicę w postrzeganiu czynów w judaizmie i w chrześcijaństwie. Według tekstów judaistycznych czyny poprzedzają człowieka na drodze przed sąd Boży i determinują wydany wyrok. W Apokalipsie na pierwszym miejscu jest wspólnota z Chrystusem, znajdująca swój wyraz w czynach. 
namizm działalności dwóch świadków - wstępuje w nich, aby na nowo ożyli $(11,11)$. To Duch przekazuje wizje Janowi $(1,10 ; 4,2 ; 17,3 ; 21,10)^{35}$.

W Ap 14,13 Duch dopowiada swoisty komentarz wzmacniający jeszcze błogosławieństwo. Ponieważ mamy tutaj przytoczone bezpośrednio słowa Ducha, nie ulega wątpliwości, że adresaci Apokalipsy zwrócą na nie uwagę, bowiem odnoszą się one do głosu płynącego wprost z nieba. Wypowiedź Ducha rozpoczyna się od uroczystego vaí, które ma podobną funkcję jak uroczyste ả $\mu \eta \dot{v}$ w 1,7 i 22,20, stanowiąc wyraziste powtórzenie tego, co zostało powiedziane wcześniej ${ }^{36}$.

To, że Duch przemawia jest bardzo ważne z trynitarnego punktu widzenia, ponieważ to oznacza, że Duch jest osobą w pełnym tego słowa znaczeniu. Jest zdolny do wyrażania siebie samego. Jest zdolny do mówienia. Nie jest On zatem w Apokalipsie bezosobową mocą. Warto tutaj spojrzeć na „kierunek”, w którym mówi Duch. Mówi On do stworzenia, potwierdzając słowa, które pochodzą z nieba. W ten sposób włącza się on w proces objawienia prawd Bożych ludziom ${ }^{37}$. D. Kotecki zauważa, że owa wypowiedź Ducha pojawia się w kontekście zgromadzenia liturgicznego. Jan (lektor) przekazuje zgromadzonej na liturgii wspólnocie to, co mówi Duch. Zatem użycza on swego głosu Duchowi Świętemu, który rozbrzmiewając najpierw w jego (Jana) wnętrzu, znajduje swoje uzewnętrznienie. W ten sposób uwidacznia się idea dostrzegalna już w listach do Kościołów, kiedy to orędzie skierowane do tych wspólnot oznacza to, co „Duch mówi do Kościołów”. Mamy tutaj zatem ponowne potwierdzenie boskiego pochodzenia całego przesłania, a zarazem legitymizację Jana jako proroka. To, co mówi Jan jest w istocie nie słowem ludzkim, ale słowem Boga przekazanym przez Ducha. Jest tak dlatego że całe orędzie, które Jan przekazuje, przekazuje $\dot{\varepsilon} v \pi v \varepsilon \dot{\mu} \mu a \tau$. Warto także zauważyć, że słowo Ducha przekazane przez Jana w 14,13b jest uzupełnieniem tego, co w 14,13a wprowadzone zostało przez polecenie: „napisz”. Można tu zatem dostrzec działanie Ducha, który jest jednocześnie Duchem natchnienia, przemawiającym przez Pismo ${ }^{38}$.

Uwzględniając kontekst, w jakim pojawia się błogosławieństwo w 14,13, a więc całą wizję, obejmującą 14,6-13, a zwłaszcza, na co wskazuje struktura tej wizji, pewien paralelizm, jaki istnieje między 14,6-7 a 14,13, można dostrzec tutaj rolę Ducha Świętego, który jest przekazicielem dobrej nowiny skierowanej do tych, którzy są daleko od Boga. W ten sposób orędzie zawarte w całej wizji 14,6-13 nie różni się od

35 Osborne, Revelation, 545.

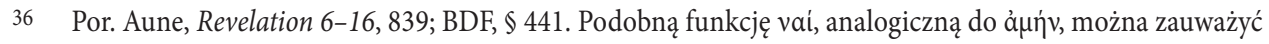
w Mt 23,26 (por. Łk 11,51); 2 Kor 1,20; Ap 1,7; 22,20.

37 Por. Leithart, Revelation, 102-104. Tu warto dopowiedzieć, że w Ap 22,17 Duch włącza się w słowa wypowiadane „w odwrotnym kierunku”, kiedy razem z Oblubienicą mówią „Przyjdź”. Wypowiedź ta - jak powszechnie uważają badacze - skierowana jest do Jezusa. Na ten temat: Kotecki, Duch Święty, 402-428; Kudasiewicz, Odkrywanie Ducha Świętego, 449-452.

38 Por. Kotecki, Duch Święty, 398-399. Z kolei J. Kudasiewicz (Odkrywanie Ducha Świętego, 429) zauważa, że „żadna księga NT nie stwierdza tak zdecydowanie swojego natchnienia prorockiego jak Apokalipsa”. 
tego, co mówi Duch do Kościołów w Ap 2-3. Zarówno w jednym, jak i w drugim tekście mamy bowiem wezwanie do nawrócenia.

\section{Wnioski}

Przeprowadzone w niniejszym opracowaniu analizy Ap 14,13 pozwalają na kilka syntetycznych wniosków. Po pierwsze, powiązanie analizowanego tekstu z całą wizją 14,6-13 pokazuje, że nie ma potrzeby traktowania wspomnianego makaryzmu jako "ciała obcego" i doszukiwania się tutaj jakichś zabiegów redakcyjnych autora. Po drugie, adresatami makaryzmu są „martwi”, których można interpretować w kategoriach duchowych. Ich umieranie „w Panu” wskazuje na proces nawrócenia, który się dokonał. Po drugie, fakt, że „martwi, którzy umierają w Panu” stają się obiektem błogosławieństwa, wiąże owo błogosławieństwo z dobrą nowiną ogłoszoną w 14,6. Dobry charakter owej nowiny polega właśnie na tym, że nawet ci, którzy dotąd byli „martwi” otrzymują zapewnienie, iż jeśli się nawrócą, otrzymają udział w odpoczynku. Po trzecie, Duch Święty jawi się tutaj jako Ten, który potwierdza obietnice dane w makaryzmie, a co za tym idzie, jest Tym, który nadaje dynamizm głoszonej „odwiecznej dobrej nowinie". Po czwarte, Duch, przemawiając w Ap 14,13, jawi się jako Osoba, która wyraża siebie samego, przekazując orędzie ludziom. Paralelne do wypowiedzi Ducha polecenie spisania treści błogosławieństwa ukazuje rolę tegoż Ducha w procesie, który nazywamy natchnieniem skrypturystycznym. Zatem Duch odgrywa tutaj bardzo ważną rolę w przekazie dobrej nowiny, która z jednej strony wzywa do nawrócenia, a z drugiej, w przypadku, kiedy to nawrócenie nastąpi, wskazuje na rychłą realizację zbawczych obietnic.

\section{Bibliografia}

Aune, D.E., Revelation 6-16 (WBC52b; Nashville, TN: Nelson 1997).

Bauckham, R., The Climax of Prophecy. Studies on the Book of Revelation (Edinburgh: Clark 1993).

Bauckham, R., „The Role of the Spirit in the Apocalypse”, Evangelical Quarterly 52/2 (1980) 66-83.

Bauckham, R., The Theology of the Book of Revelation (Cambridge: Cambridge University Press 1993).

Beale, G.K., The Book of Revelation (NIGTC; Grand Rapids, MI: Eerdmans 1999).

Beasley-Murray, G.R., The Book of Revelation (NCB; London: Oliphants 1974).

Beckwith, I.T., The Apocalypse of John. Studies in Introduction with a Critical and Exegetical Commentary (New York: MacMillan 1919). 
Berger, K., Formen und Gattungen im Neuen Testament (Uni-Taschenbücher 2532; Tübingen Basel: Francke 2005).

Bieder, W., „Die sieben Seligpreisungen in der Offenbarung des Johannes”, Theologische Zeitschrift 10 (1954) 13-30.

Biguzzi, G., „Spirito e profezia nell’Apocalisse di Giovanni”, Estudios Bíblicos 60 (2002) 503-522.

Blount, B.K., Revelation. A Commentary (Louisville, KY: Westminster John Knox 2009) [Amazon Kindle Edition].

Bousset, W., Die Offenbarung Johannis, wyd. 6 (Göttingen: Vandenhoeck \& Ruprecht 1906).

Charles, R.H., A Critical and Exegetical Commentary on the Revelation of St. John (ICC; Edinburgh: Clark 1920) I.

DeSilva, A., „Sociorhetorical Interpretation of Revelation 14,6-13. A Call to Act Justly toward the Just and Judging God", Bulletin for Biblical Research 9 (1999) 65-117.

Giesen, H., „Evangelium und Paränese. Zum Verständnis der Gerichtsaussagen in Offb 14,6-13”, Studien zum Neuen Testament und seiner Umwelt 21 (1996) 92-131.

Giesen, H., Die Offenbarung des Johannes (RNT; Regensburg: Pustet 1997).

Gundry, R.H., Commentary on Revelation (CNT; Grand Rapids, MI: Baker Academic 2011) [Amazon Kindle Edition].

Haręzga, S., Błogosławieństwa Apokalipsy (ALec 17; Katowice: Księgarnia św. Jacka 1992).

Harrington, W.J., Revelation (SP 16; Collegeville, MN: Liturgical Press 1993).

Koester, C.R., Revelation. A New Translation with Introduction and Commentary (AB 38a; New Haven, CT - London: Yale University Press 2014).

Kotecki, D., Duch Święty w zgromadzeniu liturgicznym w świetle Apokalipsy św. Jana (Rozprawy i Studia Biblijne 26; Warszawa: Vocatio 2006).

Kraft, H., Die Offenbarung des Johannes (HNT 16a; Tübingen: Mohr Siebeck 1974).

Krodel, G.A., Revelation (ACNT; Minneapolis: Augsburg 1989).

Kudasiewicz, J., Odkrywanie Ducha Świętego. Medytacje biblijne (Kielce: Jedność 1998).

Lebiedziuk, R., „Apokalipsa 14,6 - Ewangelia sądu?”, Warszawskie Studia Teologiczne 15 (2002) 67-84.

Leithart, P.J., Revelation 1-22 (London - Oxford - New York: Bloomsbury \& Clark 2018) II.

Liddell, H.G. - Scott, R., A Greek-English Lexicon (Oxford: Clarendon 1996).

MacPherson, A., „The Mark of the Beast as a "Sign Commandment" and "Anti-Sabbath" in the Worship Crisis of Revelation 12-14", Andrews University Seminary Studies 43 (2005) 267-283.

Morris, L., Revelation. An Introduction and Commentary (TNTC 20; Nottingham: Inter-Varsity 2009) [electronic edition].

Mounce, R.H., The Book of Revelation (NICNT; Grand Rapids, MI: Eerdmans 1997).

Muraoka, T., A Greek-English Lexicon of the Septuagint (Louvain - Paris - Walpole, MA: Peeters 2009).

Nwachukwu, O.O., Beyond Vengeance and Protest. A Reflection on the Macarisms in Revelation (SBL 71; New York - Washington, D.C. - Bern: Peter Lang 2005).

Osborne, G.R., Revelation (BECNT; Grand Rapids, MI: Baker Academic 2002).

Prigent, P., Commentary on the Apocalypse of St. John (tł. W. Pradels) (Tübingen: Mohr Siebeck 2001). 
du Rand, J.A., „“...Let Him Hear What the Spirit Says...”: The Functional Role and Theological Meaning of the Spirit in the Book of Revelation", Ex Auditu 12 (1996) 43-58.

Schüssler Fiorenza, E., The Book of Revelation. Justice and Judgment, wyd. 2 (Minneapolis, MN: Fortress 1998).

Siemieniec, T., „Kim są „umarli” w Apokalipsie? Propozycja interpretacji terminu oi vekpoi”, Zeszyty Naukowe Stowarzyszenia Biblistów Polskich 14 (2017) 389-425.

Siemieniec, T., „Teologiczna funkcja terminów kaıрó i х $\rho$ óvoৎ w Apokalipsie Janowej", Verbum Vitae 35 (2019) 307-342.

Siemieniec, T., „The Concept of Judgment according to Rev 11:15-18”, The Biblical Annals 7/1 (2017) 87-106.

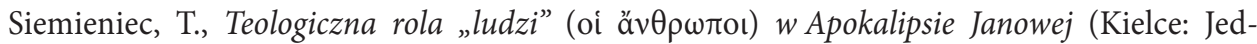
ność 2018).

Siemieniec, T., „Tożsamość „martwych” (oi vekpoi) w świetle Ap 20,4-5”, The Biblical Annals 7/4 (2017) 531-550.

Smalley, S.S., " "The Paraclete". Pneumatology in the Johannine Gospel and Apocalypse”, Exploring the Gospel of John. In Honor of D. Moody Smith (red. R.A. Culpepper - C. Black) (Louisville: Westminster John Knox 1996) 289-300.

de Smidt, K., „Hermeneutical Perspectives on the Spirit in the Book of Revelation”, Journal of Pentecostal Theology 14 (1999) 27-47.

Swete, H.B., The Apocalypse of St John. The Greek Text with Introduction, Notes and Indices (London: MacMillan 1911).

Wojciechowski, M., Apokalipsa świętego Jana. Wstęp, przekład z oryginału, komentarz (NKB. NT 20; Częstochowa: Edycja Świętego Pawła 2012).

Yeatts, J.R., Revelation (Believers Church Bible Commentary; Scottdale, PA - Waterloo: Herald Press 2003). 
